\title{
Intuitive Ideas about Chance and Probability in Children from 4 to 6 Years Old
}

\author{
Claudia Vásquez Ortiz@ $\mathbb{1}^{\mathrm{a}}$ \\ Ángel Alsina $\oplus^{\mathrm{b}}$ \\ a Pontificia Universidad Católica de Chile, Departamento de Didáctica de la Matemática, Villarrica, Cautín, Chile.

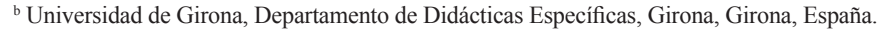 \\ Received for publication on 10 May 2019. Accepted, after revision, on 27 Jun. 2019. \\ Assigned editor: Renato P. dos Santos.
}

\begin{abstract}
This study explores intuitive ideas about chance and probability in children aged 4 to 6 . For this, we conducted an exploratory study of an instructional process with 23 pre-kindergarten and kindergarten students who had not received prior instruction on the subject. The results show that students comprehensively use elementary probabilistic language and have a first informal knowledge about other notions such as sample space, possibility of occurrence, and comparison of probabilities. We conclude that most of this knowledge (basic notions of probability) depends, to a great extent, on visual support in order to compare probability or possibility of occurrence. In other words, it is confirmed that students at these early ages need to start learning the first probabilistic notions in teaching contexts that let them visualise mathematical ideas in a concrete way, using both everyday objects and manipulative materials, and direct action on these objects. In future studies, it will be necessary to continue exploring new data that contribute to the professional development of Early Childhood Education teachers, in order to refine the planning and management of mathematical practices whose purpose is the progressive acquisition of probabilistic literacy at early ages.

Keywords: chance and probability; probabilistic literacy; probabilistic language; Child Education.

\section{Ideas Intuitivas sobre el Azar y la Probabilidad en Niños de 4 a 6 Años}

\section{RESUMEN}

Este estudio explora las ideas intuitivas sobre el azar y la probabilidad en niños de 4 a 6 años. Para ello, se ha realizado un estudio exploratorio de un proceso de instrucción con 23 alumnos de pre-kindergarten y kindergarten que no han recibido instrucción previa sobre el tema. Los resultados muestran que los alumnos usan comprensivamente lenguaje probabilístico elemental y poseen un primer conocimiento informal acerca de otras nociones como por ejemplo espacio muestral, posibilidad de ocurrencia y comparación de probabilidades. Se concluye que la mayoría de estos conocimientos (nociones básicas de probabilidad) dependen, en gran medida, del apoyo
\end{abstract}

Corresponding author: Claudia Vásquez Ortiz. E-mail: cavasque@uc.cl

\begin{tabular}{|l|l|l|l|l|l|}
\hline Acta Scientiae & Canoas & Vol. 21 & N.3 & p.131-154 & July/Aug. 2019 \\
\hline
\end{tabular}


visual para llevar a cabo las comparaciones de probabilidad o de posibilidad de ocurrencia. En otras palabras, se confirma que los alumnos de estas primeras edades necesitan iniciar el aprendizaje de las primeras nociones probabilísticas en contextos de enseñanza que permitan visualizar las ideas matemáticas de manera concreta, tanto a partir de objetos de la vida cotidiana como de materiales manipulativos, y de la acción directa sobre estos objetos. En futuros estudios va a ser necesario seguir aportando nuevos datos que contribuyan al desarrollo profesional del profesorado de Educación Infantil, para así ir afinando la planificación y gestión de las prácticas matemáticas cuya finalidad sea la adquisición progresiva de la alfabetización probabilística durante las primeras edades de escolarización.

Palabras clave: azar y probabilidad; alfabetización probabilística; lenguaje probabilístico; Educación Infantil.

\section{Ideias Intuitivas sobre Acaso e Probabilidade em Crianças de 4 a 6 Anos de Idade}

\section{RESUMO}

Este estudo explora as ideias intuitivas sobre acaso e probabilidade em crianças de 4 a 6 anos de idade. Para este fim, um estudo exploratório de um processo de instrução foi realizado com 23 pré-escola e alunos do jardim de infância que não receberam instrução prévia sobre o assunto. Os resultados mostram que os alunos utilizam linguagem probabilística compreensiva e elementar e possuem um primeiro conhecimento informal sobre outras noções como espaço amostral, possibilidade de ocorrência e comparação de probabilidades. Conclui-se que a maior parte desse conhecimento (noções básicas de probabilidade) depende, em grande parte, do suporte visual para realizar comparações de probabilidade ou possibilidade de ocorrência. Em outras palavras, confirma-se que os alunos dessas idades precoces precisam começar a aprender as primeiras noções probabilísticas em contextos de ensino que permitem visualizar ideias matemáticas de maneira concreta, tanto de objetos cotidianos quanto de materiais manipulativos, e ação direta sobre esses objetos. Estudos futuros serão necessários para continuar a fornecer novos dados que contribuem para o desenvolvimento profissional dos professores de educação infantil, a fim de afinar o planejamento e gestão da prática matemática, que tende a aquisição progressiva de alfabetização probabilística durante as idades iniciais de escolaridade.

Palavras-chave: chance e probabilidade; alfabetização probabilística; linguagem probabilística; Educação infantil.

\section{INTRODUCTION}

Currently there is general agreement that probability, due to its multiple applications in different areas of knowledge, is an important part of mathematics, so that probabilistic thinking needs to develop early, even more so if we consider that from the earliest age children develop their understanding of the world around them by means of causal and statistical reasoning - distinguishing between what is probable and what is not - as part of the development of their scientific, mathematical and social knowledge (Yurovsky et al, 2013). This has led to the incorporation of probability as a thematic area from the first ages in the school curriculum of different countries. This trend was already observed in the Curriculum and Evaluation Standard for School Mathematics to Data and Chance (NCTM, 1989), an initiative that has since gained strength and was reflected most 
recently in the Principles and Standards for School Mathematics (NCTM, 2003). The aim of these Principles and Standards is to "describe the particular characteristics of a high-quality mathematics education", and to "describe the mathematical contents and processes that students should learn" (NCTM 2003, p.11). With regard to the standard content of "Data Analysis and Probability", NCTM (2003) is intended to address basic concepts and different applications of probabilities that should enable connections to be gradually established between mathematics and other areas of knowledge, as well as with experiences of daily life. From this perspective, it propose probability should be studied continuously from Preschool Education to 6th Form. Specifically, for ages 3 to 8, it emphasises the gradual acquisition of the content associated with the development and evaluation of inferences and predictions based on data; the understanding and application of basic concepts of probability; and the discussion about probable and improbable events related to the students' experiences. In short, it is about giving students the necessary tools to develop and achieve a probabilistic literacy, understood from the perspective of Borovcnik (2016) as "the ability to use relevant methods and concepts in context and in everyday problems" (p.100) . Therefore, it is necessary to facilitate the development of critical thinking, which allows them to understand and communicate different types of information in numerous situations of daily life in which random phenomena, chance and uncertainty are present.

Many countries, such as Chile and Spain, are aware of this need, and therefore in the current Curricular Bases for Preschool Education in Chile (MINEDUC, 2018) and in the Spanish curricular guidelines for ages 0-6 (MEC, 2007), although contents related to the study of probability are not explicitly indicated, there are several learning objectives in the core of mathematical thinking that are directly related to basic notions of probability (Alsina, 2013; Vásquez, Díaz-Levicoy, Coronata \& Alsina, 2018); for example, those related to the use of quantifiers, such as: more/less, much/little, all/none, when comparing quantities of objects in everyday situations; and that will allow the children of this school level to experience and interact with the world around them, starting from, for example, probabilistic relationships, encouraging them to give meaning to the possible, random and impossible.

From this perspective and according to Batanero, Chernoff, Engel, Lee and Sánchez (2016), we must consider the practical and pedagogical problems linked to the incorporation of probability in the curricula, so that it can be used to develop the basis for the development of the probabilistic reasoning that will allow for the formal study of probability in later years. Therefore, we need to focus on the analysis of early practices linked to the teaching and learning of probability as an area of emerging research in Mathematics Education that requires attention (Ben-Zvi, Makar \& Garfield, 2018). Even though there are several works of research on probability and its teaching, these are focused on students of Primary Education and Secondary Education, with little research on experiences of teaching probability in early ages (Nikiforidou, 2018). Therefore, the present study is intended to be a preliminary exploration of intuitive ideas about chance and probability in children between 4 and 6 years old. 


\section{THEORETICAL FRAMEWORK}

Two fields in Mathematical Education theoretically support this research: probability in Early Childhood Education and probabilistic language as a way to improve probabilistic literacy.

\section{Probability in Early Childhood Education}

Probability has gradually been introduced in the mathematics curriculum, at progressively earlier ages. In the mid-20th century, Piaget and Inhelder (1951) indicated that this learning began in the stage of concrete operations (ages 7-11), although students could not understand probability until the stage of formal operations (ages 11-15), since for these authors, the acquisition of formal operations was characterised by combinatorial reasoning, the logic of propositions, proportionality, the understanding of the relativity of two movements or speeds, the understanding of mechanical equilibrium (Every action corresponds to a reaction of the same intensity but in the opposite direction), probability and correlation, which for Piaget is the last step in the understanding of probability. According to Batanero (2013), these authors had a very complex conception of the meaning of chance, complementary to the cause-effect relationship. For them, chance is the result of interference and a combination of a series of causes, that acting independently produces an unexpected result.

In a similar point of view, Fischbein $(1975,1987)$ focuses on studying and exploring the development of probabilistic thinking in children as Piaget did, emphasising the importance of primary intuitions in the development of an understanding of probabilistic notions. From Fischbein's perspective, intuitions correspond to "forms of immediate cognition in which the justifying elements, if any, are implicit" (p.5), which leads to providing categories of intuitions, distinguishing between the concept of probability as a calculation of the probabilities of occurrence of an event and the intuition of probability as a subjective and global evaluation of the probabilities of occurrence of an event. This author emphasizes, in addition, that the processes of instruction are key to favouring secondary intuitions; so he recommends "training, from early childhood, the intuitive basis as a key element in the process of learning and construction of probabilistic knowledge" (Fischbein, 1975, p.131).

A decade later, Cañizares (1997) pointed out strategies that children aged 2 to 3 use to compare probabilities. According to this author, children compare the number of possible cases (for example, they choose the box that contains the largest number of balls) and those aged 4 compare the number of favourable cases (for instance, they choose the box that contains more balls of a favourable colour). Similarly, Jones, Langrall, Thornton and Mogill (1997) propose a framework for the development of probabilistic thinking from an early age based on four central concepts: sample space, probability of an event, probability comparisons and conditional probability. In their study, they later propose 4 levels of probabilistic thinking: Level 1: associated with subjective thinking or influenced by 
irrelevant aspects; Level 2: transition between naive and subjective quantitative thinking; Level 3: use of informal quantitative thinking; Level 4: incorporation of numerical thinking and use of numerical measures to describe probabilities. For these authors, the first level corresponds to the first ages, that is, to the students of Early Childhood Education. In relation to the probabilistic thinking of this first level, Jones et al. (1999, p.488) conceive it as "the thinking of children in response to any situation of probability".

An important turning point for the advancement of teaching probability came at the start of the 21st century, when the National Council of Teachers of Mathematics proposed the incorporation of probability in teaching programmes from age 3 (NCTM, 2003). With this measure, this North American association aims to encourage, from a very early age, the teaching of knowledge that serves as a basis for the collection, description and interpretation of data, along with decision making in situations of uncertainty. To carry out these acquisitions, they propose starting from informal activities, focused on judgements that students make based on their own experiences, using terms such as "certain", "probable" or "impossible", which implies gradually starting to distinguish the phenomena determining random occurrences, along the lines already indicated by Fischbein $(1975,1987)$.

Since then, different authors have supported this initiative by providing arguments, teaching strategies, resources and classroom activities with the purpose of helping teachers of Early Childhood Education to teach probability (Alsina, 2011, 2017; Alsina \& Vásquez, 2016, 2017; Vásquez, 2018; Vásquez et al., 2018), since in general early stage teachers have little or no knowledge of the discipline of probability or the techniques for teaching it (Batanero, 2013).

Alsina (2017), for example, sets out three arguments about the incorporation of probability (together with statistics) in the Early Childhood Education curriculum: a) the importance of guaranteeing a high quality education that adjusts to social changes; b) the importance of mathematics in general, and probability in particular, in the overall development of children; and c) the importance of probabilistic literacy from the earliest ages. In addition, a teaching itinerary -inspired by the previous contributions of Godino, Batanero and Cañizares (1987)- that contemplates diverse contexts of teaching to work with probability in Preschool Education is proposed: daily life experiences, manipulatives, games, popular resources (stories and songs), digital resources and graphics (notebooks).

In addition, Alsina and Vásquez (2017) suggest teaching guidance and resources focused on the contexts of daily life and playful-manipulative materials are provided, since, according to Batanero (2013, p.5), "children are surrounded by chance from birth, in their games (drawing lots, data games, cards, etc.) and daily life experiences (meteorology, sports, etc.) ".

Parallel to these contributions, the mathematics curricula of different countries have begun to gradually incorporate the study of probability from the first ages to provide a stochastic experience for the students. Considering the different meanings of probability proposed by Batanero (2005), these studies have focused mainly on the intuitive meaning 
of probability, leaving other meanings such as the Laplacian, the frequency, the subjective or the axiomatic for higher levels.

The intuitive meaning focuses on the use of terms commonly used to refer to uncertainty, and to express the degree of belief in relation to uncertain events (Alsina \& Vásquez, 2016). From this point of view, based on the previous background, Alsina $(2011,2017)$ proposes an organisation of content, and not a prescription, which has been reformulated in which attempts are made to specify the contents of probability that should be worked with for ages 3 to 6 .

\section{The Beginnings of Probabilistic Literacy and Probabilistic Language}

Gal (2012, p.4) defines probabilistic literacy as: "the ability to access, use, interpret and communicate information and ideas related to probability, in order to participate and effectively manage the demands of functions and tasks that involve real-world uncertainty and risk." From this view, he indicates that probabilistically literate behaviour requires the joint activation of five cognitive elements (knowledge) and three dispositional elements (attitudes), which are proposed as the basic components of probabilistic literacy. These elements follow the logic used by Gal (2005) to describe the construction of statistical literacy. With respect to cognitive elements, $\operatorname{Gal}(2005,2012)$ refers to the following:

1. Big ideas: variation, randomness, independence, predictability / uncertainty. Probabilistic literacy is a dynamic and relative construction. Randomness is considered a slippery construction that has been much debated; independence implies that events are unrelated and one event cannot be predicted from another; and predictability and uncertainty are related to the state of our general knowledge about the probability of a certain event.

2. Calculating probabilities: ways to find or estimate the probability of events. To calculate probabilities, students must be familiar with how to find the probability of events, in order to understand the probabilistic statements made by others, or to generate estimates about the probability of events and communicate with others about them. This is where the views of classical, frequentist and subjective probability are useful.

3. Language: the terms and methods used to communicate about chance. Students must understand the "language of chance" that is, the various forms that are used to represent and communicate about chance and probability.

4. Context: understanding the role and implications of probabilistic issues and messages in various contexts and in personal and public discourse. Knowledge related to context is necessary from both the functional and the educational point of view. The understanding that randomness will not affect the events and processes of the real world allows people to foresee that certain events will be more predictable, while others will not.

5. Critical questions: issues to consider when dealing with probabilities. Students should know what critical questions to ask when they encounter a statement of probability 
or certainty, or when they have to generate a probabilistic estimate. The questions should refer to five elements: the context (to what extent does it involve randomness?); the source (who makes a probabilistic demand?); the process (what type of analysis is used?); the meaning of the message (what does the probabilistic statement indicate?); and reflective interpretation (what questions the message and how is it interpreted?

The three dispositional elements and the corresponding attitudes mentioned by Gal (2005) are the following:

1. Critical stance: quantitative messages that can be deceptive, unilateral, biased or incomplete (whether intentionally or not) should generate an attitude of questioning. It is therefore necessary to learn gradually to invoke spontaneously the list of questions that generate uncertainty in the face of arguments that claim to be based on data, results reports, survey conclusions or other empirical investigations.

2. Beliefs and attitudes: three constructs are distinguished referring to emotions, attitudes and beliefs. It is therefore necessary to develop gradually a positive vision of oneself as an individual capable of performing probabilistic reasoning in situations of uncertainty that are relevant, rather than based on anecdotal data or personal experiences.

3. Personal sentiments regarding uncertainty and risk (e.g., risk aversion): the degree of uncertainty or predictability experienced can be the basis of one's perception and ability to assess the risk associated with events or results of relevance to life.

We see that among the cognitive elements that Gal indicates, language is included. On this question, and starting from the basis that all the elements both cognitive and dispositional interact with each other in a complex way during real learning, Vásquez and Alsina (2017) have conducted a study focused on the stage of Primary Education in which the multiplicity is analysed of terms, oral and written expressions, symbols and representations that are used when students are intended to gradually learn the notion of probability and acquire the respective associated probabilistic language. The results show a strong predominance of terms and verbal expressions coming from the common language, which move towards probabilistic concepts.

The aim of this new study is to extend these results and explore intuitive ideas about chance and probability in children aged 4 to 6 .

\section{METHODOLOGY}

We designed an exploratory study using a qualitative research approach, in which we use the case study as a research design, since this "implies a process of inquiry characterized by the systematic and in-depth examination of cases of a phenomenon" (Bisquerra, 2009, p.309). From the perspective of research in Mathematics Education, it is assumed that this approach focuses on the description of the personal meaning of the facts, as well as the cognitive and attitudinal aspects of the participants (Vollstedt, 2015). 
This methodology has been chosen since it lets us explore intuitive ideas about chance and probability based on the analysis of concepts related to its comprehension such as sample space, possibility of occurrence, probability and comparison of probabilities in children from 4 to 6 years old.

\section{Participants}

This study was carried out with 23 students of Early Childhood Education at a private school in southern Chile. They were divided into two groups that share the same room and activities: a first group of 12 children ( 7 girls and 5 boys), aged 4 to 5 (Pre-kindergarten) and a second group of 11 children (5 girls and 6 boys) aged 5 to 6 (Kindergarten). The teacher in charge is an Early Childhood Education specialist with 6 years of experience in the classroom.

\section{Design and procedure}

The data of this research were collected through video recording of two consecutive lessons of 35 minutes of approximate duration each, in which the teacher in charge presents both groups with a probabilistic task, that is to say, learning activities whose purpose is to promote the construction of new knowledge associated with chance and probability, in order to stimulate the development of probabilistic reasoning through exploration and reflection around the resolution of problems in which uncertainty is present (Vásquez, 2018). This task is focused on the context of the celebration of the "Month of the Sea" in Chile (May), which highlights the importance of maritime heritage in the Pacific and commemorates a major naval war event.

The task was designed and planned jointly by the teacher and the head researcher and was based on the framework for the development of probabilistic thinking proposed by Jones et al. (1997). It was designed and planned with the purpose of investigating Early Childhood students' intuitive ideas about the first notions and key ideas associated with chance and probability, such as: sample space, possibility of occurrence, probability and comparison of odds. To do this, the study focused on the discussion generated by the students' experiences and their responses, with the teacher in charge providing scaffolding. It should be noted that these children have not received prior instruction on probability, but they know how to count (recognise elementary quantities of a set of elements) up to 20 . They can also manage some relationships of order of quantity with the help of the teacher.

Two cameras were used for the video recording process: a fixed one (centred on the whole class) and one in motion to capture with greater precision the interactions among the students and between the teacher and the students, in order to focus on students' questions and answers as well as how the teacher provides scaffolding and guides their 
learning. It should be noted that ethical procedures were followed for videotaping the classes, with informed consent forms signed by the teachers and parents of the children, as well as the informed assent of the children.

The probabilistic task implemented is divided into 2 major moments:

First moment: the students jointly build and decorate an aquarium with seashells, seaweed, sand, small stones, conch shells and coloured fish (coloured and cut by themselves). Later they discuss the characteristics of the living beings that can live in the sea and which are present in the aquarium, and, to motivate the students, each one is given a fish to colour.

Second moment: the teacher has a fish tank and 14 fish of the same shape and size distributed as shown in Figure 1 ( 5 red, 6 green and 3 yellow).

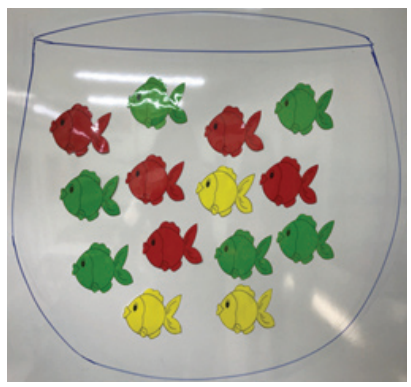

Figure 1. Visual support presented by the teacher.

The concrete material shown in Figure 1, along with visual support from the context of the fish deposited in the fish tank, were used to investigate the children's intuitive ideas about chance and probability, using the following questions (Table 1).

Table 1

Questions posed to students.

Question 1: How many fish are there in each colour?

Question 2: What colour could a fish taken out of the fish tank be? Why?

Question 3: If I want to take out a fish with my eyes closed (without looking at the fish tank), which fish is it easier to get (more likely)? Or is there no difference between getting a red, green or yellow fish?

Question 4: If I want to take out a fish with my eyes closed (without looking at the fish tank), which fish is it more difficult to get (less likely)? Why?

Question 5: Can I take an orange fish out of the fish tank? Why?

Question 6: If you could put the fish in order from the easiest-to-get fish colour (the one that is most likely to come out) to the hardest-to-get (the one that is least likely to come out), what order would they be in? Why? 
Later, in a second instance (last 20 minutes of the class), the teacher presents 2 fish tanks with the same number of fish in each, but with different colour distribution: 3 reds and 5 yellows in "fish tank 1" and 6 reds and 2 yellows in "fish tank 2" (see Figure 2) and ask the questions that are detailed in Table 2.

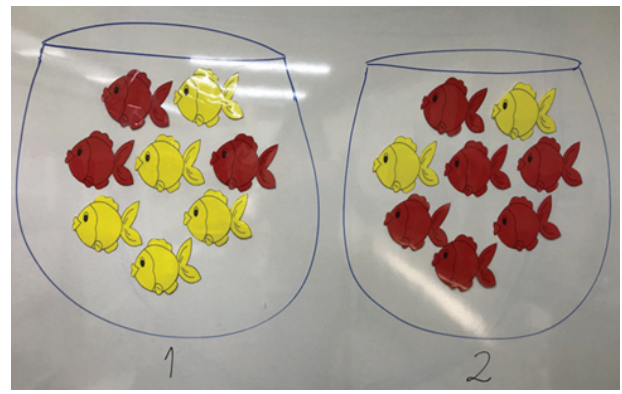

Figure 2. Visual support presented by the teacher.

Table 2

Questions posed to students.

Question 7: If I now have 2 fish tanks (Figure 2), which of them is easier to get a yellow fish from? Why?

This activity is intended to find out how students of this age manage to compare probabilities in situations where the number of possible cases is equal, and the number of favourable cases changes.

As can be seen, the probabilistic tasks posed by the teacher to the students (Tables 1 and 2) are aligned with the guidelines of the NCTM (2003), since at these levels, ideas about probability should be informal and focused on the judgements that the students emit based on their own experiences. Activities should be carried out that underlie experimental probabilities, such as throwing dice, but the main purpose of such activities should be in other branches, such as the numerical one.

\section{Analysis of the Data}

To carry out the analysis of the video data, the analytical model proposed by Powell, Francisco and Maher (2003, p.413) was used, which contemplates a sequence of seven phases: 1) intentional visualisation; 2) description of the video data; 3 ) identification of critical events; 4) transcription; 5) coding; 6) argument construction; and 7) narrative composition. These phases are interactive and allow access to the development of mathematical ideas and mathematical reasoning as a complex and non-linear process, taking the students' ideas about the proposed topic as input, as well as the thoughts presented in their conversations, productions and gestures 
In the first three phases video recordings were observed repeatedly, which were segmented into 5-minute intervals, creating a record with time stamps and brief descriptions-descriptive and non-interpretative or inferential-of specific episodes (critical events) of interest for the study. In this process NVivo 12 software was used, as it facilitates the identification and location of episodes of interest on which to focus attention; that is, the information obtained was shown through the video recordings until its content was familiar, facilitating the formation of a first impression about the probabilistic language used by the students.

Once a general overview of the lessons was obtained, the transcription and coding phase of the critical events closely analysed elements such as language and the flow of ideas, facilitating the selection of extracts of interest (evidence) for the preliminary and unconnected construction of the lesson's argument. Finally, the observations made from the critical events were clarified through joint analysis sessions between the head researcher and the teacher. The above procedure enabled us to refine the interpretations and produce a finished narrative composition of the lessons in the study in order to explain early intuitive ideas about chance and probability in children aged 4 to 6 .

\section{RESULTS}

In accordance with the objective of this study, which seeks to provide ideas and explanations about the intuitive ideas about chance and probability in children from 4 to 6 years old, the results and evidence are presented taking into account the structure of the probabilistic task raised by the teacher. For the description of the results, extracts have been transcribed with the questions and answers of the teacher and students. We present the main findings from each task below.

\section{Question 1. How many fish are there in each colour?}

Once the class has begun and the context of the probabilistic task has been introduced in the theme of the month of the sea, the teacher shows the set of fish in the fish tank and asks the students how many fish there are in total, and how many of each colour. The purpose of the task is for students to identify the cardinality of the fish set (14 in total) and to distinguish how many fish there are of each colour, and in this way begin to become familiar with some of the elements of the sample space, understood as the set that corresponds to all the possible results of an experiment.

To facilitate the participation of the students, the teacher constantly questions them about how they can respond to the different questions, encouraging them to express and share their ideas and strategies, and also provides adequate time for this and for the children to become familiar with the material used.

Teacher: Children, look here, let's look at the fish tank, there are little fish in this fish tank, right? What colour are those fish? 


\section{Students}

in chorus: Green, red and yellow.

Teacher: Very good! They are red, green and yellow. Now look here, how many fish are there of each colour? How many greens? How many reds and how many yellows?

Martin: $\quad$ Mmm, that question is very difficult ... There are lots of fish.

Andrea: I can think of how to find out.

Teacher: Tell us Andrea, how can we know how many fish there are of each colour?

Andrea: You have to take them all out of the fish tank and count them, but if they were real fish you couldn't, they would die, right?

Teacher: Very good! That was a good idea of Andrea's, wasn't it? Does anyone have another idea or way of counting them?

Students

in chorus: No.

Teacher: OK, then let's take all the fish out of the fish tank and let's all count together how many they are (the teacher takes out the fish one by one and starts counting along with the students one by one).

Students

in chorus: One, two, three, four, five, six, seven, eight, nine, ten, eleven...

Carolina: I know! (Raising her hand) There are 14 fish.

Teacher: Carolina, well done!! There are 14 fish in total; did you all understand?

Students

in chorus: Yes.

Teacher: Now, how can we know how many fish there are of each colour?

Josefa: $\quad$ The same way as we did before, but now we count the colours.

Teacher: That's a good idea Josefa; let's count the reds first, do you think?

Students: Yes

Teacher: Josefa, come here and count the red fish (starts counting with the students, returning the red fish to the fish tank one by one) one, two, three, four...

Josefa: $\quad$ There are 5 .

Teacher: Good, Josefa! Now go to your place. Children, so we don't forget that there are 5 red fish; shall we write it on the board? 
Students

in chorus: Yes.

Teacher: Now let's count how many yellows and how many greens there are (the teacher uses the same procedure, but now she counts the fish herself as she returns the fish one by one to the fish tank).

José: $\quad$ There are 3 yellows; those are just a few.

Teacher: Very good José! (The teacher writes 3 yellow fish on the board)

Teacher: Let's count the green fish, one, two, three, four, five, six...

Andrea: Seven, it's seven.

Teacher: Very good! (She now notes the 6 green fish on the board (see Figure 3)). We already know that there are 5 red, 3 yellow and 6 green fish. All of you have done very well.

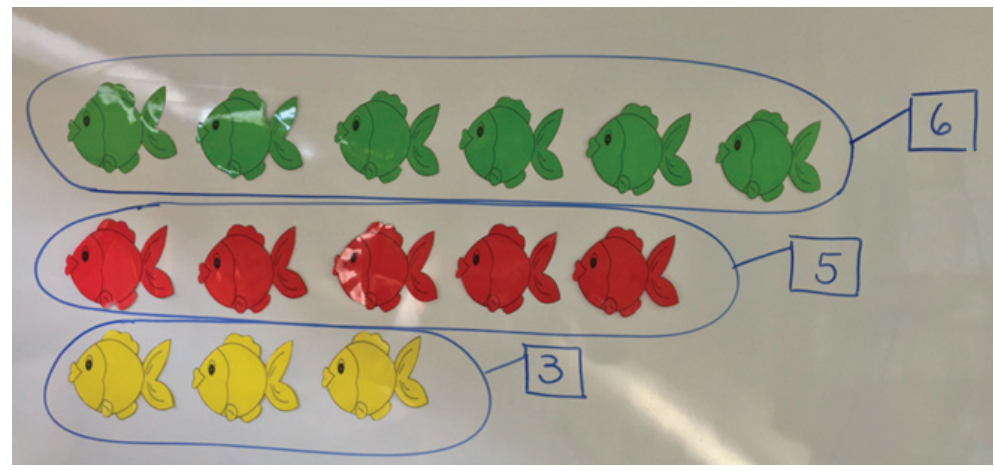

Figure 3. Visual support presented by the teacher.

As can be observed, the students do not present / display any difficulty identifying the different colours of the fish, and later can count to determine how many fish there are of each colour as well as how many fish there are in total inside the fish tank. It should be noted that the teacher arranges the fish of each colour in a line to make it easy for the children to count them. In this way, they determine the total cardinality of the fish set and the cardinality of each subset according to the fish colour (Figure 4). This type of questions and activity will allow you to identify easily later the sample space of the experiment of extracting a fish from the fish tank. 


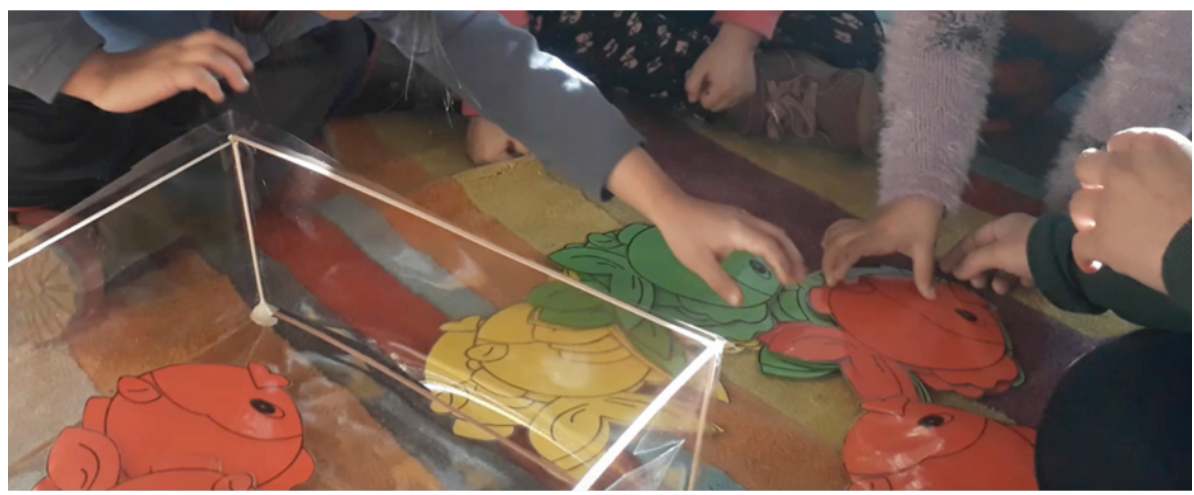

Figure 4. Cardinality of each subset of fish.

\section{Question 2. What colour could a fish taken out of the fish tank be? Why?}

Once the cardinality of the fish set has been identified, as well as how many of each colour there are, the teacher asks the students what colour the fish taken out of the fish tank might be. To observe if students can determine the sample space of the experiment "extract a fish from the fish tank", that is, that the students manage to identify all the possible results of the experiment "extract a fish from the fish tank". In this case, the sample space corresponds to $\mathrm{E}=\{$ red, green, yellow $\}$.

Teacher: Now I am going to ask you another question, are you concentrating?

Students

in chorus: Yes.

Teacher: Listen carefully! If I asked you to take out a fish with your eyes closed, what colour fish could you take out of the tank?

Martin: Green.

Teacher: Very good! What other colour?

José: $\quad$ Red

Teacher: Excellent! And what other colour?

Martin: Yellow.

Teacher: Could we get another colour?

Students

in chorus: No.

Teacher: Good! Very good! So, we can only take out 3 colours: green, red and yellow. Why?

Some

students: Because there are no more colours.

Teacher: Very good! We only have three colours of fish in this fish tank: green, red and yellow. 
A large part of the students is able to identify without difficulty the set of all the possible results of the experiment, that is, the sample space. They also identify that you cannot extract fish of other colours, since in there are only green, yellow and red fish in the tank, which shows that they can distinguish between a possible event and impossible events.

\section{Question 3. If I want to take out a fish with my eyes closed (without looking at the fish tank), which fish is it easier to get (more likely)? Or is there no difference between getting a red, green or yellow fish? Why?}

Through this question the teacher seeks to see if students can distinguish the favourable cases associated with the possibility of occurrence of an event and, for this, it is necessary to consider three simple non-equiprobable events produced by the composition of the fish tank. To answer the question, just compare absolute quantities (number of fish per colour).

Teacher: $\quad$ Now, let's suppose that we all have our eyes closed. Everyone close your eyes, cover your eyes with your hands, just like Florencia, cover your eyes with your little hands, all with your eyes covered. Now answer the next question without looking. If I want to take out a fish with my eyes closed, what is easier to get out? Which one am I most likely to get? Or, is there no difference between getting a red, green or yellow fish?

Students

in chorus: $\mathrm{Mmmmm}$

Teacher: What is easier to get out? A green, red or yellow fish?

Tomás: $\quad M m m$ green.

Teacher: Why, Tomás? Everyone look now, uncover your eyes and look here. Why is it easier to take out a green fish? Does anyone think different? Or, is there no difference between getting a red, green or yellow fish?

Tomás: Because... I don't know... mmm...

Teacher: Remember, how many fish do we have of each colour? (Questions, pointing to the board (see Figure 3)).

Tomás: I Inow, because there are more green ones, there are more than yellow and red ones.

Teacher: Very good Tomás! There are more green ones than yellow and red fish, remember that there are 5 red and 3 yellow fish, so what Tom says is correct, there are 6 green fish. And what do we know about number 6?

Andrea: It's bigger than 5 and 3.

Teacher: Very good! So if I take out a fish with my eyes closed there is more chance of getting a fish that is...?

Students'

chorus: Green. 


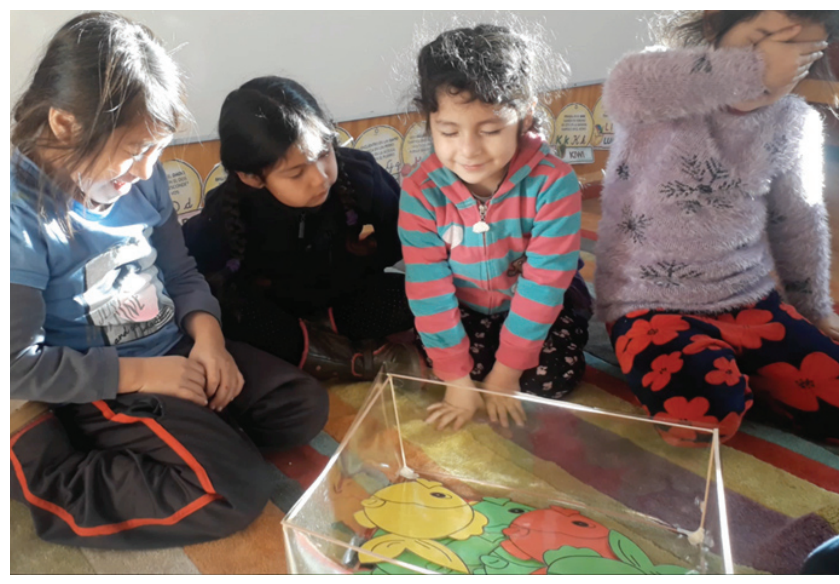

Figure 5. Comparison of the quantity of fish of each colour.

The students, through the scaffolding of the teacher, have been able to identify, by means of the comparison of absolute quantities, the event that has greater possibilities of occurring, distinguishing that there are differences that can influence in taking out a fish of a certain colour, that would be associated with the amount of fish per colour. It is also observed that to establish the comparison, the students depend to a large extent on visual support, since they formulate their answers based on the information that the teacher has written on the board with the quantities of fish associated with each colour (see Figure 3 and 5).

\section{Question 4. If I want to take out a fish with my eyes closed (without looking at the fish tank), which fish is it more difficult to get (less likely)? Why?}

As in the previous question, the teacher seeks to see if the students can distinguish the favourable cases associated with the possibility of occurrence of an event in which it is necessary to consider three simple non-equiprobable events product of the composition of the fish tank.

Teacher: Now listen! If I wanted to take another fish with my eyes closed again, which is most difficult to get out? Which one is not very likely?

Students

in chorus: Green.

Teacher: Are you sure? Listen carefully to the question; which is more difficult to get out?

Students: Errr...

Teacher: For a bit of help, remember, how many fish are there in each colour? How many red? How many greens? How many yellows? (Questions, pointing to the board (see Figure 3)). 
Florencia: Yellow.

Teacher: Florencia says it's more difficult for her to take out a yellow fish, why?

Florencia: Because there aren't as many yellow ones as the other colours, there are 3.

Teacher: Does anyone think different from Florence?

Andrea: $\quad M e$ ! There are fewer reds than greens too.

Teacher: Andrea tells to us that it is also more difficult to get a red fish, do you agree?

Students

in chorus: Yes.

Teacher: Look, how many red fish are there? And how many yellow fish are there? (Pointing to the board (see Figure 3)).

Students

in chorus: red and 3 yellow.

Teacher: Very good! So which fish is it less likely for me to get out of the fish tank with my eyes closed? What colour?

Some

students: Yellow.

Teacher: Why?

Florencia: Because there are fewer yellow ones than red and green ones, there are only 3.

Teacher: Very good Florencia! Florencia is right, as there are only 3 yellow fish and number 3 is smaller than 5 and 6 , so it is more difficult to get a yellow fish.

Many students respond well to the question, basing their arguments on the absolute comparison of fish quantities according to colour, which leads them to establish which fish is less likely to be extracted.

\section{Question 5. Can I take an orange fish out of the fish tank? Why?}

This question is intended to observe if students can distinguish possible or impossible events and discuss their degree of possibility of occurrence.

Teacher: Now I'm going to ask you another question about the fish tank. If I want to get an orange fish out of the tank, can I? Is it possible?

Students

in chorus: No.

Teacher: Why not?

Students

in chorus: Because there aren't any fish that colour, there are only red, green and yellow fish. 
Teacher: Very good! I can only take one fish, red, green or yellow; there is no other colour.

The students as a whole manage to distinguish between an impossible event and a possible one, arguing that it is not possible to extract an orange fish since there are no fish of that colour in the tank.

\section{Question 6. If you could put the fish in order from the easiest-to-get fish colour (the one that is most likely to come out) to the hardest-to-get (the one that is least likely to come out), what order would they be in? Why?}

This question associated with the context of the proposed probabilistic task is intended to observe whether students can describe events as possible or not and discuss their degree of possibility of occurrence. Specifically, students should predict the possibility of occurrence of results of simple experiments and order them, as a first approximation to a qualitative scale of degrees of possibility of occurrence of an event.

Teacher: Listen! We have the last challenge today. If I had to put the fish in order from the easiest-to-get fish colour, the one that is most likely, to the hardest-to-get, the one that is least likely to come out, what order would they be in?

Students

in chorus: $\mathrm{Mmmm}$.

Teacher: Think carefully. Remember how many fish there are of each colour.

Tomás: $\quad$ The hardest to get out is the yellow because there are only 3 and the one that has more chances of leaving is green because there are 6, there are more of them.

Teacher: Very good, Tomás! Do all of you understand?

Some

students: No.

Teacher: Look, how many yellows are there? And how many greens are there?

Antonia: I know.

Teacher: Let's listen to Antonia.

Antonia: First goes green because there are 6, it is the largest number, then mmm ... there are 5 reds, 5 is smaller than 6, and the last one has the least, you have 3 yellows, it is the smallest of all.

Teacher: Well done Antonia! Did you all understand?

Some students: No

Teacher: To understand it, why don't we take the fish from the fish tank and stick them on the blackboard? So, we see how to order them from the one that is most likely to take out to the one that is least likely. 
Students

in chorus: Yes.

Teacher: Can you tell me now what order to put them in? If we go from the one that is most likely to the one that is least likely to come out.

Students

in chorus: Green, red and yellow

Teacher: Excellent! Very good! The order is correct because I have to look at the number of fish I have in each colour, as Antonia said.

The students manage to identify, with the mediation of the teacher, that there are different degrees of possibility of extracting a fish of a certain colour and they associate it with the comparison of absolute quantities, allowing this strategy to establish an order of possibilities of occurrence. This allows them to visualise that there are intermediate degrees between the certain and the impossible, which will be key to the development of probabilistic ideas in higher education.

\section{Question 7. If I now have 2 fish tanks, which of them is easier to get a yellow fish from? Why?}

This activity investigates students' intuitive ideas for comparing the possibility of occurrence of results of simple experiments.

Teacher: OK children!!! Yesterday we were working with coloured fish, remember?

Students

in chorus: Yes.

Teacher: Today, instead of 1 fish tank, we 'll work with 2 fish tanks. Let's count! How many fish are there in each one?

Students

in chorus: One, two, three, four, five, six, seven and eight.

Teacher: Very good! How many fish in total are in the first fish tank?

Students

in chorus: Eight.

Teacher: $\quad$ And the second fish tank, how many fish do you have in total?

Students

in chorus: The same as the other one, eight.

Teacher: Very good! The two fish tanks have the same total number of fish. What colours are the fish in each fish tank?

Students

in chorus: Red and yellow

Teacher: Very good! Now, how many red fish are there in the first fish tank? And how many yellow fish? 
Some

students: 3 red and 5 yellow.

Teacher: Very good! There are 5 yellow fish and 3 red fish. And in the second tank? How many red fish and how many yellow fish are there?

Students

in chorus: 6 red and 2 yellow.

Teacher: Perfect! So, of these two fish tanks that we have here, which of them is easier to get a yellow fish out of?

Elizabeth: Out of the first one.

Teacher: Elizabeth, why do you say it's easier to get a yellow fish out of the first fish tank?

Elizabeth: Because there are more than the others, there are 5.

Teacher: Which others?

Elizabeth: Than the yellow fish in the other fish tank, there are only 2.

Teacher: Very good! Then it is more likely that I will take out a yellow fish if I am going to fish in the first fish tank.

As can be observed, the arguments of the students to establish the relations of comparison between the possibilities of occurrence are of numerical type, since they compare the absolute quantities of the favourable cases in relation to the possible cases. From which it follows that many of the students are able to differentiate the possible events (favourable cases depending on the total cases) linked to the experiment of extracting a yellow fish from each of the fish tanks (Figure 6).

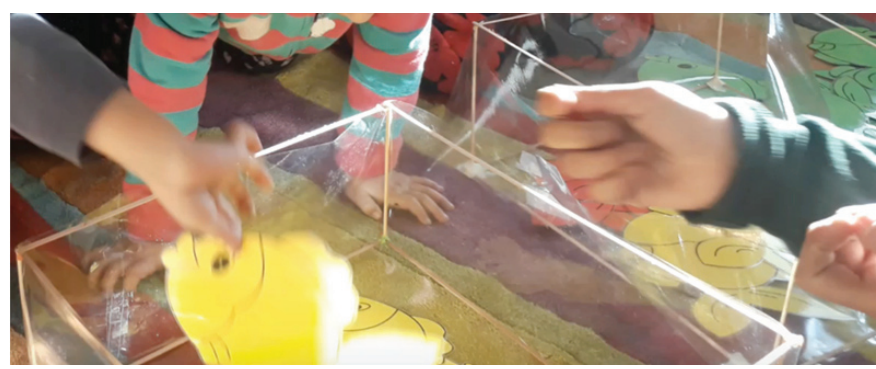

Figure 6. Comparison of the possibility of occurrence.

\section{FINAL CONSIDERATIONS}

Through this study we have explored in the first instance the understanding of chance and probability in children from 4 to 6 years old in order to provide evidence on probabilistic thinking at these ages, which can help to provide guidelines for suitable implementation of the treatment of probability in Early Childhood Education, and to lay the bases at this scholastic stage for probabilistic literacy. 
Various authors and international organisations have indicated that students at the Early Childhood stage can begin to acquire probabilistic knowledge at an early age (Alsina, 2013, 2017, Cañizares, 1997, Fischbein, 1975, 1987, Jones et al., 1997, 1999, NCTM, 2003, Vásquez et al., 2018, among others). Most of these authors and organisations associate this first knowledge with the intuitive meaning of probability, which as indicated refers to the comprehensive use of colloquial terms (certain, probable, impossible) to refer to uncertainty and express a degree of belief in relationship to uncertain events (Batanero, 2005; Alsina \& Vásquez, 2016; Vásquez \& Alsina, 2017).

In our study these preliminary data are consolidated, since a large part of the participants (without observing differences between the types of responses of the students belonging to the pre-kindergarten and kindergarten group) have used the probabilistic language comprehensively, confirming that they are, in their majority, at the level 1 of probabilistic thinking proposed by Jones et al. (1997, 1999). In addition, the results of our study allow us to further refine the previous results and expand knowledge about the understanding of chance and probability in pre-school students, as it has been evidenced through the different tasks that many students have the understanding and informal knowledge necessary to explore probabilistic notions and key ideas associated with chance and probability, such as sample space, possibility of occurrence, probability, and comparison of probabilities, and qualitative scale of degrees of possibility of occurrence. They also have an initial probabilistic thinking that allows them to distinguish between a possible event and an impossible one. Given the complexity and abstraction of some of these concepts, such as the notion of "sample space", the verification of acquisition by students at early ages can generate some controversy both in the context of research in children's mathematics education and in research on probability teaching methods. Here it should be noted that in some recent preliminary studies (Nikiforidou, 2018; Alsina \& Salgado, 2019) it has already become clear that students at these first levels are beginning to understand the notion of sample space, although these authors clarify that it is from a first intuitive approach to the concept necessary both for more formal learning of the concept at higher levels and for the gradual acquisition of probabilistic literacy.

Another relevant fact of our study, which also contributes to a better understanding of what probabilistic knowledge children in pre-school education possess and how they acquire it, is the fact that most of this knowledge (basic notions of probability) depends, to a large extent, on visual support for comparing probability or possibility of occurrence. In other words, it confirms that students at these early ages need to start learning the first probabilistic notions in teaching contexts that let them visualise mathematical ideas in a concrete way, both from everyday objects and manipulative materials, and direct action on these objects, as already pointed out by Alsina (2017) when proposing an itinerary for teaching probability in Early Childhood Education.

Finally, the role of teachers in the development of probabilistic thinking at an early age should also be considered, mainly through mediation and appropriate scaffolding. Here, the tasks outlined have shown, for example, that the participants in the study have the understanding and informal knowledge necessary to establish, with the teacher's 
support, a qualitative scale associated with degrees of possibility of occurrence, basing their arguments on absolute comparisons of quantities of elements of each subset of the sample space, placing the context of the probabilistic task as a key element at these ages at the time of developing probabilistic thinking. Through the analysis carried out, it has become clear that the acquisition of this type of achievement is mainly due to the planning and management of the tasks that start with the approach of challenges; to the formulation of good questions that invite students to reason, argue and justify their actions and mathematical ideas; or to an environment of mathematical communication in the classroom, in which interaction, negotiation, dialogue and the use of increasingly accurate probabilistic language have been present. In short, as already noted by Alsina (2011, 2017), it must involve the systematic work of mathematics content in general and probability in particular through the mathematical processes of problem solving, reasoning and testing, communication, connections and representation (NCTM, 2003).

From this perspective, future studies will need to continue providing new data that contribute to the professional development of Early Childhood Education teachers, in order to refine the planning and management of mathematical practices whose purpose is the gradual acquisition of probabilistic literacy during early childhood education.

\section{ACKNOWLEDGEMENTS}

Work carried out under the FONDECYT project No. 11150412, financed by the National Commission of Scientific and Technological Research of Chile.

\section{AUTHORS' CONTRIBUTIONS STATEMENTS}

C.V.O. and A.A. adapted the methodology to this context, created the models, performed the activities, collected the data, and analysed the data. Both authors discussed the results and contributed to the final version of the manuscript.

\section{REFERENCES}

Alsina, Á. \& Vásquez, C. (2016). De la competencia matemática a la alfabetización probabilística en el aula: elementos para su caracterización y desarrollo. UNION, Revista Iberoamericana de Educación Matemática, 48, 41-58.

Alsina, Á. \& Vásquez, C. (2017). Hacia una enseñanza eficaz de la estadística y la probabilidad en las primeras edades. Revista Didasc@lia: Didáctica y Educación, 8(4), 199-212.

Alsina, Á. (2012). La estadística y la probabilidad en educación infantil: conocimientos disciplinares, didácticos y experienciales. Didácticas Específicas, 7, 4-22.

Alsina, Á. (2017). Contextos y propuestas para la enseñanza de la estadística y la probabilidad en Educación Infantil: un itinerario didáctico. Épsilon, 95, 25-48. 
Alsina, Á. and Salgado, M. (2019). Ampliando conocimientos matemáticos en Educación Infantil: la incorporación de la probabilidad. Revista de Estudios y Experiencias en Educación (REXE).

Batanero, C. (2005). Significados de la probabilidad en la educación secundaria. RELIME, $8(3), 247-264$.

Batanero, C. (2013). La comprensión de la probabilidad en los niños: ¿qué podemos aprender de la investigación? En J.A. Fernandes, P. F. Correia, M.H. Martinho, and F. Viseu, (Eds.), Atas do III Encontro de Probabilidades e Estatística na Escola (pp.1-13). Braga: Centro de Investigação em Educação da Universidade do Minho.

Batanero, C., Chernoff, E. J., Engel, J., Lee, H. S., \& Sánchez, E. (2016). Research on teaching and learning probability. Cham: Springer.

Ben-Zvi, D., Makar, K., \& Garfield J. (Eds.) (2018). International handbook of research in statistics education. Cham: Springer.

Bisquerra, R. (2009). Metodología de la investigación educativa. Madrid: La Muralla. Borovcnik, M. (2016). Probabilistic thinking and probability literacy in the context of risk. Educação Matemática Pesquisa, 18(3), 1491-1516.

Cañizares, M. J. (1997). Influencia del razonamiento proporcional y combinatorio y de creencias subjetivas en las intuiciones probabilísticas primarias. Tesis doctoral, Universidad de Granada, Granada.

Fischbein, E. (1975). The intuitive sources of probabilistic thinking in children. Dordrecht: Reidel.

Fischbein, E. (1987). Intuition in science and mathematics. Dordrecht: Reidel.

Gal, I. (2005). Towards "probability literacy" for all citizens: Building blocks and instructional dilemmas. In G.A. Jones (Ed.), Exploring probability in school. Challenges for teaching and learning (pp.39-63). Dordrecht, The Netherlands: Kluwer.

Gal, I. (2012). Developing probability literacy: Needs and pressures stemming from frameworks of adult competencies and mathematics curricula. In S.J. Cho (Ed.), Proceedings of the 12th International Congress on Mathematical Education (pp.1-7), Seoul, Korea: Springer.

Godino, J. D., Batanero, C., \& Cañizares, M. J. (1987). Azar y probabilidad. Fundamentos didácticos y propuestas curriculares. Madrid: Síntesis.

Jones, G. A., Langrall, C. W., Thornton, C. A., \& Mogill, A. T. (1999). Students' probabilistic thinking in instruction. Journal for Research in Mathematics Education, 30(5), 487-519.

Jones, G., Langrall, C., Thornton, C., \& Mogill, T. (1997). A framework for assessing and nurturing young children's thinking in probability. Educational Studies in Mathematics, 32, 101-125.

Ministerio de Educación (2018). Bases Curriculares para la Educación Parvularia. Santiago de Chile: Unidad de Curriculum y Evaluación.

Ministerio de Educación y Ciencia (2007). Boletín oficial del Estado. ORDEN ECI/2211/2007, del 20 de julio, por la que se establece el currículo y regula la ordenación de la Educación Primaria. Madrid.

NCTM (1989). Curriculum and Evaluation Standards for School Mathematics. Reston, VA: NCTM. 
NCTM (2003). Principles and standards for school mathematics. Reston, Va.: The National Council of Teachers of Mathematics (Trad. Castellana, Principios y estándares para la educación matemática. Sevilla: Sociedad Andaluza de Educación Matemática Thales, 2003). New York: Springer-Verlag.

Nikiforidou, Z. (2018). Probabilistic Thinking and Young Children: Theory and Pedagogy. In A. Leavy, M. Meletiou-Mavrotheris and E. Paparistodemou (Eds.), Statistics in Early Childhood and Primary Education (pp.21-34). Dordrecht: Springer Netherlands.

Piaget, J. \& Inhelder, B. (1951). La genèse de l'idèe de hasard chez l'enfant. Paris: Presses Universitaires de France.

Powell, A. B., Francisco, J. M., \& Maher, C. A. (2003). An analytical model for studying the development of learners' mathematical ideas and reasoning using videotape data. Journal of Mathematical Behavior, 22(4), 405-435.

Vásquez, C. \& Alsina, Á. (2017). Lenguaje probabilístico: un camino para el desarrollo de la alfabetización probabilística. Un estudio de caso en el aula de Educación Primaria. Bolema, 31(57), 454-478.

Vásquez, C. (2018). Surgimiento del Lenguaje Probabilístico en el Aula de Educación Primaria. REnCiMa, 9(2), 374-389.

Vásquez, C., Díaz-Levicoy, D., Coronata, C., \& Alsina, Á. (2018). Alfabetización estadística y probabilística: primeros pasos para su desarrollo desde la Educación Infantil. Cadernos Cenpec, 8(1), 54-179.

Vollstedt, M. (2015). To See the Wood for the Trees: The Development of Theory from Empirical Interview Data Using Grounded Theory. In A. Bikner-Ahsbashs, C. Knipping, and N. Presmeg (Eds.), Approaches to Qualitative Research in Mathematics Education (pp.23-48). Dordrecht: Springer Netherlands.

Yurovsky, D., Boyer, T., Smith, L. B., \& Yu, C. (2013). Probabilistic cue combination: Less is more. Developmental Science, 16(2), 149-158. 